\title{
Do Multi-year Applications of Bacillus thuringiensis subsp. israelensis for Control of Mosquito Larvae Affect the Abundance of B. cereus Group Populations in Riparian Wetland Soils?
}

\author{
Salome Schneider ${ }^{1,2}$ (D) Tania Tajrin ${ }^{1}$ - Jan O. Lundström ${ }^{3,4} \cdot$ Niels B. Hendriksen ${ }^{5}$. \\ Petter Melin $^{6} \cdot$ Ingvar Sundh ${ }^{1,7}$
}

Received: 20 January 2017 / Accepted: 30 May 2017 /Published online: 10 June 2017

(C) Springer Science+Business Media New York 2017

\begin{abstract}
Bacillus thuringiensis subsp. israelensis (Bti) is a soil-borne bacterium affiliated to the Bacillus cereus group $(\mathrm{Bcg})$ and has been used in biocontrol products against nematoceran larvae for several decades. However, knowledge is limited on whether long-term Bti application can affect the structure of indigenous communities of Bcg and the overall abundance of Bti. Using species- and group-specific quantitative PCR assays, we measured the Bcg- and Bti-abundances in riparian wetlands in the River Dalälven floodplains of central Sweden. On five occasions during one vegetative season, soil samples were collected in alder swamps and wet meadows which had been treated with Bti for mosquito larvae control during the preceding 11 years, as well as in untreated control
\end{abstract}

Electronic supplementary material The online version of this article (doi:10.1007/s00248-017-1004-0) contains supplementary material, which is available to authorized users.

Salome Schneider

salome.schneider@wsl.ch

1 Department of Microbiology, Swedish University of Agricultural Sciences (SLU), Uppsala, Sweden

2 Biodiversity and Conservation Biology, Swiss Federal Research Institute WSL, Birmensdorf, Switzerland

3 Department of Medical Biochemistry and Microbiology (IMBIM), Uppsala University, Uppsala, Sweden

4 Swedish Biological Mosquito Control Project, Nedre Dalälvens Utvecklings AB, Gysinge, Sweden

5 Department of Environmental Science, Aarhus University, Roskilde, Denmark

6 Swedish Chemicals Agency, Sundbyberg, Sweden

7 Department of Molecular Sciences, Swedish University of Agricultural Sciences (SLU), Uppsala, Sweden sites and well-drained forests in the same area. The average abundance of Bcg in alder swamps was around three times higher than in wet meadows. Across all sites and habitats, the Bti treatments had no effect on the Bcg-abundance, whereas the Bti-abundance was significantly higher in the treated than in the control sites. However, for individual sampling sites, abundances of Bti and Bcg were not correlated with the number of Bti applications, indicating that added Bti possibly influenced the total population of Bti in the short term but had only a limited effect in the longer term. The findings of this study increase the understanding of the ecology of Bti applications for mosquito control, which can facilitate environmental risk assessment in connection with approval of microbiological control agents.

Keywords Bacteria $\cdot$ Biological control · Mosquito larvae · qPCR $\cdot$ Long-term effect $\cdot$ Sweden

\section{Introduction}

The soil-borne bacterium Bacillus thuringiensis (Bt) is a globally distributed insect pathogen. It belongs to the Bacillus cereus group (Bcg) which also includes B. cereus, B. anthracis, and the genetically more distant Bacillus mycoides, Bacillus pseudomycoides, and Bacillus weihenstephanensis [1]. $\mathrm{Bt}$ is most closely related to $B$. cereus [2], which is known as a human pathogen, causing diarrheal and emetic diseases [3]. Based on their high similarity, it is likely that $\mathrm{Bt}$ and $B$. cereus have a common ancestor [4]. Both species occur ubiquitously in the environment, and Hendriksen [2] argued that the ecology of Bt should be considered in association with that of $B$. cereus.

$\mathrm{Bt}$ is the most widely used biological control agent and one of the most successful microbiological pest control systems [5]. More specifically, B. thuringiensis subsp. israelensis (Bti) 
has been widely used for biological control of mosquito and black fly larvae. During sporulation, Bti produces parasporal inclusions containing protoxins. The lethal effect is manifested only after larval ingestion of the protoxins, which when solubilized in the high $\mathrm{pH}$ of the gut are cleaved to four toxins that react with specific gut cells of nematoceran larvae $[6,7]$.

Long-term application of Bti for mosquito control has been performed in several habitat types, including ecologically sensitive areas [8-12]. In Sweden, large-scale applications of Bti in natural environments have been conducted since 2001 in irregularly flooded wet meadows and alder swamps of the River Dalälven floodplains. Several of the treated sites are located in Natura 2000 areas which include one National Park and a number of Nature Reserves [13]. Concerns have been raised regarding the potential influence of Bti on nontarget organisms in the River Dalälven region and, besides the environmental risk assessments related to product authorization, specific permits are required when using pest control agents in protected natural environments and when distributed from aircraft. Additionally, little is known regarding the abundance of indigenous Bti and Bcg collectively in riverine wetlands, as well as regarding environmental persistence and potential dispersal of added Bti spores in the longer term $[8,14]$.

Most studies of the overall abundance of Bti in the environment have relied on cultivation-dependent techniques [14], while recently, cultivation-independent quantification tools have been introduced [8]. Cultivation approaches are comparatively insensitive, laborious, and hampered by the morphological and phenotypic similarities between B. cereus and Bt. Additionally, Bti-abundances in field samples such as leaf litter can be estimated by quantifying the Cry toxins, which are mainly responsible for the insecticidal effects of Bti, by enzyme-linked immunosorbent assays (ELISAs; [15]). Cultivation-independent techniques based on quantitative real-time PCR (qPCR) help to overcome the similarities within the Bcg and allow for relatively fast and cost-efficient analyses of environmental samples.

We recently developed a cultivation-independent qPCR tool targeting chromosomal DNA that allows for detection and quantification of Bcg and Bti in soil samples [16]. In this study, we investigated whether long-term Bti applications affected overall Bti- and Bcg-abundances in riverine wet meadows and alder swamps, using these tools.

\section{Material and Methods}

\section{Study Areas}

We investigated the effect of Bti application on overall Btiand Bcg-abundances in soils of wet meadows, alder swamps, and well-drained coniferous forests located in the River Dalälven floodplains around Lake Färnebofjärden in
Central Sweden. The wet meadows were dominated by sedges and also had scattered Salix-bushes and trees [13]. The herb layer of the alder swamps was characterized by sedges, grasses and other herbs, while the tree layer was dominated by Alnus glutinosa and Betulaceae spp. [13]. The well-drained coniferous forest sites had an herb layer of mosses, scattered low shrubs (Ericaceae spp.), and the tree layer consists mainly of Picea abies and some Pinus sylvestris, and were located well above areas influenced by flooding events.

\section{Bti Treatment for Mosquito Control}

VectoBac-G® (Valent Biosciences, Libertyville, FL) containing B. thuringiensis subsp. israelensis AM65-52 (200 international toxic units [ITU] $\mathrm{mg}^{-1}$ and $1.3 \times 10^{12}$ colony-forming units (CFU) $\mathrm{kg}^{-1}$ ) has been applied to selected areas with an average dosage of 13-15 $\mathrm{kg}$ per ha [17] by aerial application since 2001 (Table 1). Some sites with recurring high larvae production after flooding events were treated twice in some years while several sites were not treated each year. The latest VectoBac-G® application before the first sampling for this study took place in May and/or July 2012.

\section{Sampling Sites}

Sampling was conducted in 2013 at six sites in wet meadows, six in alder swamps, and three in well-drained forest (Table 1). Three of the wet meadow sites had been treated with VectoBac-G ${ }^{\circledR}$, while three remained untreated. Of the alder swamp sites, four had received VectoBac$G \circledast$ and two were untreated. The three well-drained forest sites had never been treated. Air temperatures were measured once daily with seven loggers placed $1 \mathrm{~m}$ aboveground from May to September 2013. The distance between the loggers and the corresponding sampling sites was between 0 and $7 \mathrm{~km}$. There were no VectoBac-G® treatments at any site during the sampling season 2013, due to low densities of larvae. At each site, three subsites were defined along a 30-m long transect. GPS coordinates were recorded for each subsite (Table 1).

\section{Soil Sampling}

Soil was collected once every month, in May (17-20), June (18-19), July (17-18), August (16-17), and October (22-25) 2013. Five soil cores of $2.5 \mathrm{~cm}$ diameter and $10 \mathrm{~cm}$ depth were taken evenly distributed within $1 \mathrm{~m}^{2}$ at each subsite. Plant debris was removed and the five soil cores were pooled, yielding one soil sample from each subsite. Soil samples were transported in cooling boxes to the laboratory and stored at $4{ }^{\circ} \mathrm{C}$ until further processing. Subsequently, samples were passed through a 4-mm sieve and subjected to dry weight 
Table 1 Characteristics of the 15 study sites in alder swamps (AS), wet meadows (WM), and well-drained forest (WDF)

\begin{tabular}{|c|c|c|c|c|c|c|c|c|c|}
\hline \multirow[t]{2}{*}{ Subsite } & \multirow[t]{2}{*}{ Location } & \multirow[t]{2}{*}{ Lat } & \multirow[t]{2}{*}{$\log$} & \multirow[t]{2}{*}{ Habitat } & \multirow{2}{*}{$\begin{array}{l}\text { Number VectoBac } ₫ \\
\text { treatments }\end{array}$} & \multicolumn{4}{|c|}{ Temperature $\left({ }^{\circ} \mathrm{C}\right)$} \\
\hline & & & & & & May & June & July & August \\
\hline 1.1 & Valmbäcken east & 60.296814 & 16.841541 & AS & 11 & 14.5 & 16.3 & 17.9 & 15.5 \\
\hline 1.2 & Valmbäcken east & 60.296724 & 16.842786 & AS & 11 & & & & \\
\hline 1.3 & Valmbäcken east & 60.296645 & 16.842440 & AS & 11 & & & & \\
\hline 2.1 & Valmbäcken west & 60.296673 & 16.841193 & AS & 11 & & & & \\
\hline 2.2 & Valmbäcken west & 60.296413 & 16.841131 & AS & 11 & 14.5 & 16.3 & 17.9 & 15.5 \\
\hline 2.3 & Valmbäcken west & 60.296017 & 16.841299 & AS & 11 & & & & \\
\hline 3.1 & Koverstamyran north & 60.294390 & 16.832297 & AS & 0 & & & & \\
\hline 3.2 & Koverstamyran north & 60.294403 & 16.831863 & AS & 0 & 14.5 & 16.3 & 17.9 & 15.5 \\
\hline 3.3 & Koverstamyran north & 60.294297 & 16.831661 & AS & 0 & & & & \\
\hline 4.1 & Koverstamyran south & 60.291774 & 16.830497 & AS & 6 & & & & \\
\hline 4.2 & Koverstamyran south & 60.291781 & 16.830859 & AS & 6 & 14.5 & 16.3 & 17.9 & 15.5 \\
\hline 4.3 & Koverstamyran south & 60.291584 & 16.830672 & AS & 6 & & & & \\
\hline 6.1 & Fågle & 60.245278 & 16.726449 & AS & 1 & & & & \\
\hline 6.2 & Fågle & 60.245036 & 16.726407 & AS & 4 & 15.9 & 16.4 & 18.2 & 14.4 \\
\hline 6.3 & Fågle & 60.245118 & 16.726156 & AS & 4 & & & & \\
\hline 7.1 & Öby fäbodar & 60.217828 & 16.745940 & AS & 0 & & & & \\
\hline 7.2 & Öby fäbodar & 60.217517 & 16.746707 & AS & 0 & 15.5 & 17.1 & 18.8 & 16.0 \\
\hline 7.3 & Öby fäbodar & 60.217633 & 16.746819 & AS & 0 & & & & \\
\hline 5.1 & Fågle & 60.243812 & 16.732042 & WM & 5 & & & & \\
\hline 5.2 & Fågle & 60.243868 & 16.731628 & WM & 5 & 15.9 & 16.4 & 18.2 & 14.4 \\
\hline 5.3 & Fågle & 60.243728 & 16.732455 & WM & 0 & & & & \\
\hline 8.1 & Öby fäbodar & 60.220125 & 16.752357 & WM & 0 & & & & \\
\hline 8.2 & Öby fäbodar & 60.220230 & 16.752721 & WM & 0 & 15.5 & 17.1 & 18.8 & 16.0 \\
\hline 8.3 & Öby fäbodar & 60.220282 & 16.752903 & WM & 0 & & & & \\
\hline 9.1 & Mälholmen & 60.248941 & 16.784031 & WM & 7 & & & & \\
\hline 9.2 & Mälholmen & 60.249371 & 16.782906 & WM & 7 & 16.8 & 18.0 & 20.2 & 18.4 \\
\hline 9.3 & Mälholmen & 60.249198 & 16.783335 & WM & 7 & & & & \\
\hline 10.1 & Hornberg & 60.292282 & 16.747299 & WM & 11 & & & & \\
\hline 10.2 & Hornberg & 60.292514 & 16.747486 & WM & 12 & 16.4 & 17.4 & 19.1 & 17.4 \\
\hline 10.3 & Hornberg & 60.292674 & 16.747654 & WM & 12 & & & & \\
\hline 11.1 & Ormpussen & 60.127503 & 16.778106 & WM & 0 & & & & \\
\hline 11.2 & Ormpussen & 60.127507 & 16.777620 & WM & 0 & 16.5 & 18.6 & 20.8 & 18.0 \\
\hline 11.3 & Ormpussen & 60.127593 & 16.776849 & WM & 0 & & & & \\
\hline 12.1 & Skekarsbomyran & 60.210600 & 16.847211 & WM & 0 & & & & \\
\hline 12.2 & Skekarsbomyran & 60.210364 & 16.847510 & WM & 0 & 15.8 & 18.1 & 20.6 & 17.2 \\
\hline 12.3 & Skekarsbomyran & 60.210344 & 16.847852 & WM & 0 & & & & \\
\hline 13.1 & Ormpussen & 60.131662 & 16.818445 & WDF & 0 & & & & \\
\hline 13.2 & Ormpussen & 60.131744 & 16.818304 & WDF & 0 & 16.5 & 18.6 & 20.8 & 18.0 \\
\hline 13.3 & Ormpussen & 60.131780 & 16.818359 & WDF & 0 & & & & \\
\hline 14.1 & Skekarsbomyran & 60.193069 & 16.896448 & WDF & 0 & & & & \\
\hline 14.2 & Skekarsbomyran & 60.193095 & 16.896557 & WDF & 0 & 15.8 & 18.1 & 20.6 & 17.2 \\
\hline 14.3 & Skekarsbomyran & 60.192777 & 16.896961 & WDF & 0 & & & & \\
\hline 15.1 & Fors & 60.301148 & 16.716661 & WDF & 0 & & & & \\
\hline 15.2 & Fors & 60.301157 & 16.716698 & WDF & 0 & 16.4 & 17.4 & 19.1 & 17.4 \\
\hline 15.3 & Fors & 60.301174 & 16.716825 & WDF & 0 & & & & \\
\hline
\end{tabular}

At each site, soil samples were collected at three subsites within a 30-m transect. Average monthly air temperatures were calculated for each site based on daily temperature measured with loggers from May to September 2013

determination, soil DNA extraction, or spore spiking. In October 2015, soil samples were collected at each site and sent to AgriLab (Uppsala, Sweden) for analyzing chemical soil parameters (Online Resource 1). 


\section{Soil DNA Extraction}

Soil DNA was extracted from $250 \mathrm{mg}$ (wet weight) subsamples using the PowerLyzer PowerSoil DNA-Isolation Kit (Mo Bio Laboratories, Carlsbad, CA) according to the manufacturer's instructions. A FastPrep-24 instrument (MP Biomedicals, Santa Ana, CA) was used for bead-beating of the soil samples (6000 rpm for $45 \mathrm{~s}$ ). Quality of soil DNA was examined by electrophoresis in $1 \%(w / v)$ agarose with ethidium bromide staining. DNA concentration was determined with Pico-Green (Invitrogen, Carlsbad, CA) using a Qubit fluorometer (Invitrogen).

\section{Quantitative Real-Time PCR}

QPCR was performed with Bcg- and Bti-specific primer pairs Bcg1 (Bcg1_for AACAGGCTCCATACAATGGTAT; Bcg1_rev TGGTAGCGTTTCTTCGTCTTAT) and Bti1 (Bti1_for CAAACATTTCATTCCAATAACA; Bti1_rev ATACTGTGTGGGATGCTTATTA). Both primer pairs target chromosomal DNA and yield PCR fragments with sizes of approximately 250 (Bcg) and 190 (Bti) bp, respectively [16]. Reaction volumes of $20 \mu \mathrm{l}$ contained $10 \mathrm{ng}$ soil DNA, $1 \times$ IQ SYBR green supermix (Bio-Rad, Hercules, CA), $0.1 \mathrm{mg} \mathrm{ml}^{-1}$ bovine serum albumin (BSA; GE Healthcare, Piscataway, $\mathrm{NJ}$ ), and $0.5 \mu \mathrm{M}$ of each primer (Life Technologies, Carlsbad, CA). QPCR was performed as analytical triplicates, for each of the three soil samples at each site, in a CFX 96 realtime system (Bio-Rad). Cycling conditions were $5 \mathrm{~min}$ of initial activation at $95^{\circ} \mathrm{C}$, followed by 35 cycles of $30 \mathrm{~s}$ of denaturation at $95^{\circ} \mathrm{C}$ and $1 \mathrm{~min}$ of annealing at 65 and $59{ }^{\circ} \mathrm{C}$ for Bcg- and Bti-specific amplifications, respectively, and finally $30 \mathrm{~s}$ of extension at $72{ }^{\circ} \mathrm{C}$. Following amplification, a melting curve analysis was performed to confirm expected product sizes, ranging from 55 to $95{ }^{\circ} \mathrm{C}$ with $0.5{ }^{\circ} \mathrm{C}$ increments for $5 \mathrm{~s}$.

Plasmids containing a fragment amplified with the Bcg1 or Btil primers from DNA of $B$. thuringiensis subsp. israelensis AM65-52 [16] were used as standards for quantification. Plasmid DNA was linearized using Not1-HF (New England Biolab, Ipswich, MA) and quantified with qPCR conditions as described above. Tenfold serial dilution series were prepared containing $2 \times 10^{6}-0.2$ targets $\mu l^{-1}$. Quantification standard reactions contained $5 \mu \mathrm{l}$ plasmid dilution and were performed in triplicate. The threshold line and the sample-specific threshold cycle numbers $\left(C_{\mathrm{T}}\right)$ were determined using the default parameters of the qPCR instrument software (Bio-Rad CFX Manager, version 3.1). Efficiency values $(E)$ and correlation coefficients $\left(R^{2}\right)$ were calculated for each standard quantification curve of $C_{\mathrm{T}}$ against the logarithm of the number of input copies of the target. The densities of Bcg and Bti were determined as copy numbers per gram soil dry weight $\left(g^{-1} \mathrm{dw}\right)$ for each analytical replicate.

\section{Recovery of Bacterial DNA}

Recovery of bacterial DNA from soil was estimated by spiking samples with known numbers of Bt spores. Spores of strain AM65-52 (used in the VectoBac-G® product) were obtained by inoculating liquid T3 medium [18] followed by incubation at $28^{\circ} \mathrm{C}$ for 5 days [19]. The cultures were checked for spores and crystals by phase-contrast microscopy. The number of CFU was determined by spreading $50 \mu \mathrm{l}$ of $10^{5}$ dilutions on T3 agar (five replicates), after elimination of vegetative cells in the spore suspension by heating to $75^{\circ} \mathrm{C}$ for 15 min followed by DNase treatment [20].

Sieved soil from each habitat type (VectoBac-G®-treated and untreated wet meadows and alder swamps, VectoBac$\mathrm{G}($-untreated well-drained forest) was spiked with different numbers of spores $\left(3.7 \times 10^{4}-3.7 \times 10^{6} \mathrm{CFU} \mathrm{g}^{-1}\right.$ soil $)$ by addition directly to $250 \mathrm{mg}$ soil.

\section{Data Analysis}

Average copy numbers per gram dw were calculated from analytical triplicates if at least two of them were above the threshold of detection. Otherwise, abundance was considered to be below the detection limit and data was entered as zero.

For statistical analyses, mean values were calculated for each of the three subsites of all the 15 sites. Relationships between bacterial abundances and environmental factors were tested using a generalized mixed model, "glmmADMB," in the R package "glmmADMB" [21]. Data from the sites in welldrained forest were excluded when analyzing the treatment effect on Bti-abundances, since none of the well-drained forest sites had been treated with VectoBac-G®. Various models were tested and evaluated based on the AIC value, where lower values indicate stronger model fit. The random factor "Site" was used to account for repeated measurements at the same site over time. Habitat type, VectoBac-G® application (treated or untreated), and sampling time point were included as fixed factors. Because of an unbalanced design for treated and untreated alder swamps, no "Treatment" $\times$ "Habitat type" interaction could be tested for this habitat. The strongest model fit for Bcg was found for the model $y \sim$ Habitat type and for Bti for $y \sim($ Habitat type + Treatment $) \times$ Sampling occasion. A negative binomial error structure was applied, because of the characteristics of count data and the detected overdispersion. For both the Bcg and Bti data sets the "log" link function was chosen. To avoid potential errors introduced by this function, Bti data were parallel transformed. The Markov Chain Monte Carlo (MCMC) model was run with 1000 iterations to examine the influence of chosen variables on Bcg- and Bti-abundances.

Using the function "cor.test" in the package "stats" in the software R [22], Pearson correlations were calculated between soil parameters and average Bcg- or Bti-abundances over all sampling time points and between Bcg- or Bti-abundances 
and average air temperatures at each site for May, June, July, and August.

DNA extraction efficiency from soil samples spiked with spores was tested by analysis of variance (ANOVA) and Tukey's post hoc tests using the function "aov" and "TukeyHSD" in the package "MASS" [23] in the software R.

Figures were generated using the functions "boxplot" and "coefplot" in the packages "car" [24] and "coefplot" [25] in the software R, respectively.

\section{Results}

On each sampling occasion, a total of 45 soil samples (five occasions giving 225 samples in total, on average consisting of 65.1 [ \pm 10.2$] \mathrm{g}$ soil $\mathrm{dw}$ ) were collected and screened for Bcg- and Bti-abundances. The average DNA concentration of the soil samples was estimated to $68.1( \pm 13.9) \mu \mathrm{g} \mathrm{g}^{-1} \mathrm{dw}$. The $10 \mathrm{ng}$ soil DNA added to each qPCR reaction corresponded on average to $254.0( \pm 68.5) \mu \mathrm{g} d w$ of soil. The detection limit over all soil samples was calculated as $4.2( \pm 1.0) \times 10^{4}$ targets $\mathrm{g}^{-1} \mathrm{dw}$, when ten copies per reaction was set as the lower limit for detection (based on the quantification standard curves). The abundance of Bcg was above the detection limit in $68 \%$, and of Bti in $24 \%$, of the samples (Online Resource 2). In the samples that were positive for Bcg and Bti (analyzing treated and untreated sites together), average abundances were $7.7( \pm 9.6)$ and $3.4( \pm 3.5) \times 10^{5}$ copies $^{-1}$ dw, respectively.

The only soil parameter which was significantly correlated with Bcg- and Bti-abundances was plant-available potassium content $(R=0.63$ and $R=0.55, P<0.05$ for Bcg and Bti, respectively, Online Resource 1$)$.

The Bcg- and Bti-abundances were the highest in July, which was the only sampling occasion where both were detected at all sites (Figs. 1 and 2, Online Resource 2). The average Bti-abundance across all sites in July was 3.0 $( \pm 3.1) \times 10^{5}$ copies $g^{-1} \mathrm{dw}$. At all other occasions, the average abundance was below $7.5 \times 10^{4}$ copies $\mathrm{g}^{-1} \mathrm{dw}$, however with standard deviation ranging from 2.8 to $7.4 \times 10^{4}$ (Online Resource 2; Fig. 2).

Habitat type was the only factor, which was significantly related to Bcg-abundance (Fig. 1; Online Resource 3). In the alder swamps, Bcg was detected in all subsites at all sampling occasions, but in wet meadow and dry forest, only in 76.7 and $53.3 \%$ of the subsite/sampling occasion combinations, respectively (Online Resource 2). The average numbers of Bcg in alder swamps and wet meadows were $9.7( \pm 11.3)$ and 3.3 $( \pm 5.1) \times 10^{5} \mathrm{~g}^{-1} \mathrm{dw}$, respectively, which was significantly higher than in the well-drained forest with 4.7 $( \pm 8.2) \times 10^{4} \mathrm{~g}^{-1} \mathrm{dw}$.

There was no overall influence of VectoBac-G® application on Bcg-abundance $(\mathrm{AIC}=1964.4$, coefficient $=0.7493$,
$\mathrm{SE}=0.7319, P=0.306)$. However, for alder swamps in May, the average number of Bcg in VectoBac-G® treated sites was $2.0( \pm 1.2) \times 10^{6} \mathrm{~g}^{-1} \mathrm{dw}$, three times higher than in the untreated sites with $6.4( \pm 2.0) \times 10^{5} \mathrm{~g}^{-1} \mathrm{dw}$. Such a difference was not observed for wet meadows with $2.7( \pm 5.4)$ and 3.4 $( \pm 4.7) \times 10^{5} \mathrm{~g}^{-1} \mathrm{dw}$ at untreated and treated sites, respectively.

For the abundance of Bti, there was no overall habitat effect as for Bcg (data not shown). On the other hand, for Bti, some of the interaction terms of habitat type and sampling time point were significant (Online Resource 4). Thus, significant interactions were found between May, June, and August as well as between July and samples from June and August, the latter with very low Bti-abundances (Fig. 2). In the welldrained forest, Bti-abundance was generally low and above the detection limit only in July (Online Resource 2).

The numbers of Bti targets in soil were significantly influenced by the VectoBac-G® treatment as well as the interaction between treatment and sampling date. The VectoBac-G® product contains $1.3 \times 10^{9}$ spores $\mathrm{g}^{-1}$; thus, theoretically, $1.8 \times 10^{5}$ spores per $\mathrm{cm}^{2}$ reached the ground on each treatment occasion. Without any spore loss and using the average dry

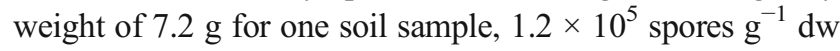
was added to the $0-10 \mathrm{~cm}$ depth layer with each treatment. The average Bcg- and Bti-abundances at untreated wetland sites excluding July were $4.3( \pm 5.2) \times 10^{5}$ and 0.2 $( \pm 1.2) \times 10^{4}$ copies $g^{-1} \mathrm{dw}$, respectively. Thus, one application of VectoBac-G® on average corresponds to 0.3 and 62 times the abundance of indigenous Bcg and Bti, respectively. In May, in five treated sites out of seven, all samples were positive for Bti with a minimum of $10^{5} \mathrm{~g}^{-1} \mathrm{dw}$ (Online Resource $2)$. In contrast, in the untreated sites, Bti was only detected in July and in October at one site in the alder swamp with 3.1 $( \pm 5.3) \times 10^{4}$ targets $\mathrm{g}^{-1} \mathrm{dw}$ (Online Resource 2$)$. For pairwise comparisons, the model containing the interaction between treatments and sampling time as single random factor was run. Bti numbers in VectoBac-G®-treated sites in May (15.9 $[ \pm 4.0] \times 10^{5}$ copies $\left.\mathrm{g}^{-1} \mathrm{dw}\right)$ and from treated $(2.3$ $[ \pm 2.4] \times 10^{5}$ copies $)$ and untreated $\left(3.7[ \pm 3.6] \times 10^{5}\right.$ copies $)$ sites in July were significantly higher than all sampling time points and treatment interactions with no Bti detectable (Online Resource 4). There was no significant difference between the VectoBac-G®-treatment interaction terms between May and July.

DNA extraction and quantification efficiency were estimated by adding up to $3.7 \times 10^{6}$ spores $\mathrm{g}^{-1}$ to soils from the different habitat types (Table 2 ). The efficiency varied between 0 and $29 \%$ for individual samples and was of similar range both when using pure spore suspensions and after addi-

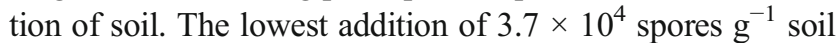
theoretically resulted in numbers below the detection limit of Bti in soil, assuming the soil samples did not contain Bti. So, it was not unexpected that several of the samples spiked with the lowest number of spores were negative for Bti (Table 2). 


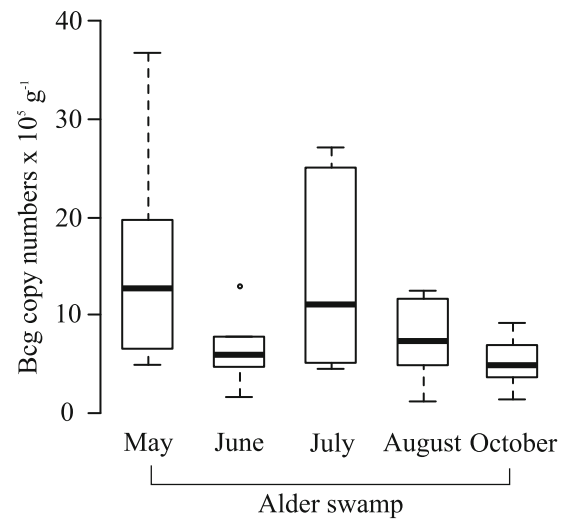

A

Fig. 1 Density of the Bacillus cereus group $(B c g)$ in soil samples collected from three habitat types of the River Dalälven floodplains, Sweden. PCR-based detection and quantification using the primers Bcg1_for and Bcg1_rev [16]. Dots indicate sites with Bcg-abundances

Independently of the number of spores added, habitat type had an influence on the DNA recovery; however, the differences were moderate and were significant only for untreated alder swamp and wet meadows soils (Online Resource 5).

\section{Discussion}

\section{Abundance of Bcg and Bti}

Using recently developed molecular detection and quantification methods [16], we detected Bcg and Bti in all habitat types, however with strong spatial and temporal variations (Figs. 1 and 2). Data were highly zero inflated and standard deviations for samples collected at the same site were therefore high. With an average of $9.3 \times 10^{4}$ copies $\mathrm{g}^{-1} \mathrm{dw}$, Bti-abundances in treated areas found in this study were of similar magnitude to previous reports. Thus, Bti-abundance of treated sediments of woodland ponds and open areas of salt water in France was around $10^{4} \mathrm{CFU} \mathrm{g}^{-1}$ soil [14] and in soils of a natural wetland after 22 years of Bti treatment in Switzerland $10^{3}$ to $10^{6}$ spores $\mathrm{g}^{-1}$ soil [8]. However, our study also presents data on Bti-abundances in untreated areas, which were on average $7.3 \times 10^{4}$ copies $\mathrm{g}^{-1} \mathrm{dw}$ in the wetlands and well-drained forests we sampled.

One study [26] reported abundance of indigenous Bti- and B. thuringiensis/cereus-like bacteria (using cultivationdependent methods and samples collected in October, and before any Bti was applied in this area) of up to 2 and $5 \times 10^{5} \mathrm{CFU} \mathrm{g}^{-1}$ wet soil, respectively, in the Nordmyran wet meadow located at the southern shore of lake Färnebofjärden where the present study was conducted. Although their numbers were reported per gram wet soil, they are of comparable magnitude with the numbers of the present study of up to $9.2 \times 10^{4}$ and $1.7 \times 10^{6} \mathrm{~g}^{-1}$ $\mathrm{dw}$ for Bti and Bcg, respectively, in untreated sites in October. In the present study, based on quantification with PCR, the average

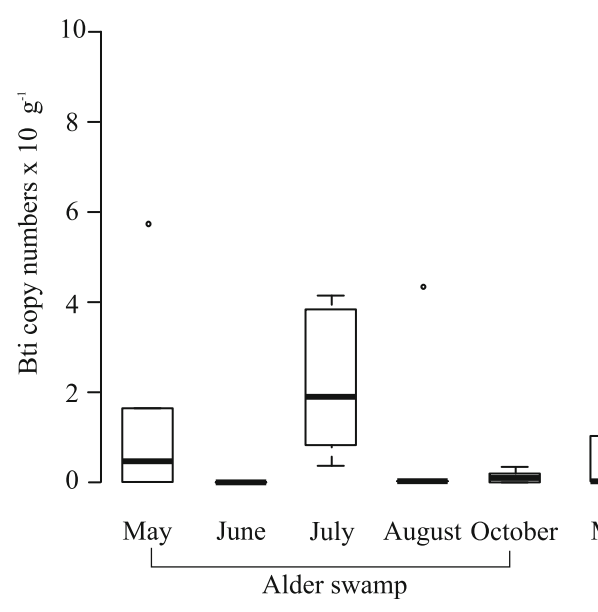

Fig. 2 Density of Bacillus thuringiensis subsp. israelensis (Bti) in soil samples collected from three habitat types of the River Dalälven floodplains, Sweden. PCR-based detection and quantification using the
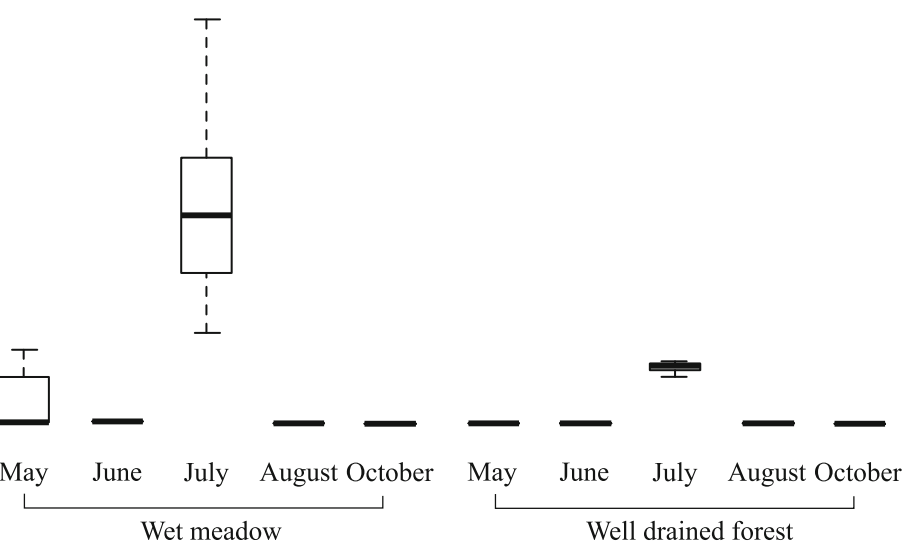

primers Bti1_for and Bti1_rev [16]. Dots indicate sites with Btiabundances outside of the confidence interval defined by 1.5 times the interquartile range 
Table 2 Recovery of spiked Bacillus DNA from soils of the River Dalälven floodplains, Sweden, and from pure spore suspensions

\begin{tabular}{|c|c|c|c|c|}
\hline Soil type & $\begin{array}{l}\text { Water content } \\
\text { in soil }\end{array}$ & $\begin{array}{l}\text { Number of CFU added } \\
\text { per gram of soil }\end{array}$ & Number $^{\mathrm{a}}$ & Recovery $\pm \mathrm{SD}$ \\
\hline \multirow[t]{3}{*}{ Untreated alder swamp } & \multirow[t]{3}{*}{$0.66 \pm 0.00$} & 37,440 & $2 / 3$ & $0.19 \pm 0.16$ \\
\hline & & 374,400 & $3 / 3$ & $0.15 \pm 0.07$ \\
\hline & & $3,744,000$ & $3 / 3$ & $0.15 \pm 0.05$ \\
\hline \multirow[t]{3}{*}{ Bti treated alder swamp } & \multirow[t]{3}{*}{$0.52 \pm 0.00$} & 37,440 & $0 / 3$ & $0 \pm 0$ \\
\hline & & 374,400 & $3 / 3$ & $0.15 \pm 0.04$ \\
\hline & & $3,744,000$ & $3 / 3$ & $0.12 \pm 0.01$ \\
\hline \multirow[t]{3}{*}{ Untreated wet meadow } & \multirow[t]{3}{*}{$0.71 \pm 0.01$} & 37,440 & $0 / 3$ & $0 \pm 0$ \\
\hline & & 374,400 & $3 / 3$ & $0.08 \pm 0.04$ \\
\hline & & $3,744,000$ & $3 / 3$ & $0.06 \pm 0.02$ \\
\hline \multirow[t]{3}{*}{ Bti treated wet meadow } & \multirow[t]{3}{*}{$0.51 \pm 0.01$} & 37,440 & $0 / 3$ & $0 \pm 0$ \\
\hline & & 374,400 & $3 / 3$ & $0.09 \pm 0.03$ \\
\hline & & $3,744,000$ & $3 / 3$ & $0.13 \pm 0.06$ \\
\hline \multirow[t]{3}{*}{ Untreated well-drained forest } & \multirow[t]{3}{*}{$0.22 \pm 0.00$} & 37,440 & $0 / 3$ & $0 \pm 0$ \\
\hline & & 374,400 & $3 / 3$ & $0.13 \pm 0.02$ \\
\hline & & $3,744,000$ & $3 / 3$ & $0.18 \pm 0.04$ \\
\hline \multirow[t]{3}{*}{ Pure spore suspensions } & - & $468^{\mathrm{b}}$ & $2 / 3$ & $0.10 \pm 0.09$ \\
\hline & - & $4680^{b}$ & $3 / 3$ & $0.12 \pm 0.14$ \\
\hline & - & $46,800^{\mathrm{b}}$ & $3 / 3$ & $0.12 \pm 0.07$ \\
\hline
\end{tabular}

Real-time PCR amplification with DNA extracts from spiked samples, using the Bti primers Bti1_for and Bti1_ rev. The recovery is given in relative proportion \pm standard deviation (SD)

${ }^{\text {a }}$ Number of replicate extracts showing detectable amplification out of the total number of replicate extracts

${ }^{\mathrm{b}}$ Number of spores added to the DNA extraction directly without any soil contribution of Bti to Bcg was $19.3 \%( \pm 56.8)$, which is of a similar magnitude as found by Eskils et al. [26], even though their data relied on different methods. Consequently, two independent studies have shown that Bti is naturally occurring in the Dalälven floodplains around Lake Färnebofjärden in Central Sweden, in the same area where VectoBac-G® is applied on a regular base.

A possible explanation for the especially high Btiabundance in our samples from July is an unusually high proportion of vegetative cells. It is possible that the majority of Bti cells in July were vegetative, since pasteurization of a subselection of soil samples resulted in strong reduction of Bti-abundance (unpublished observation). High proportion of vegetative cells of $\mathrm{Bt}$ in environmental samples has been demonstrated in earlier studies, e.g., 40 and $50 \%$ of B. thuringiensis subsp. kurstaki in the rhizosphere of dandelion and quackgrass, respectively [27]. Additionally, it was estimated that $50 \%$ of B. thuringiensis subsp. kurstaki detected in the gut of earthworms were vegetative cells [27]. Aboveground, vegetative cells were also shown to be present in lepidopteran larvae at phylloplane [28]. Similarly high proportions of $\mathrm{Bt}$ vegetative cells were found aboveground on clover [29]. However, the absence of relationships between Bti-abundance and soil and other parameters in our study (such as low numbers of floodwater mosquito larvae) gave no clear clues why vegetative growth of Bcg should have been especially high before the sampling in July. The only relationship between Bti-abundance and environmental factors was with plant available potassium content in soil, but we have not been able to find a conclusive explanation for that correlation. However, Wakisaka et al. [30] showed that strains of Bt produced endotoxins in liquid media containing $>3 \mathrm{mM} \mathrm{K}^{+}$ compared to $\mathrm{K}^{+}$-deficient media under fermenting conditions. This relationship needs to be confirmed for Bti populations exposed to high amounts of potassium in the environment, along with information regarding the accessibility for Bti of plant available potassium. Overall, higher Bcg-abundances were found in the alder swamps than in the other habitat types (Fig. 2). This might be a consequence of the fact that open grassland is more exposed to temperature changes between day and night as well as to dryness during summer [31]. In contrast, the closed canopy in alder forests gives more stable temperatures and constant humidity during summer.

\section{Effects of VectoBac-G® Treatments on Abundance of Bcg and Bti}

Overall, the effects of long-term application of VectoBac$\mathrm{G}{ }^{\circledR}$ on Bcg-populations were moderate. In May 2013, Btiabundances in subsites treated with VectoBac-G® were between 0 and 0.9 times the total number of spores applied since the beginning of VectoBac- ${ }^{\circledR}$ application in this 
area. In October, only two subsites were positive for Bti with 0.1 and 0.4 times the number of applied spores (Online Resource 2). However, the variation in abundance of indigenous Bti in untreated areas was rather high and can be expected to exceed the 62 times theoretical increase induced by one VectoBac-G® treatment. The fact that Bti was detected only in $30 \%$ or less of treated subsites in May, June, August, and October in our study indicates that the added spores did not accumulate. This outcome is in line with the findings of Duchet et al. [14], who found no evidence for spore accumulation from one year to another. Nevertheless, specific cases have been reported where spores germinate, bacteria proliferate, and new spores and crystals are formed but this new spore production did not lead to spore accumulation over years [14, 15]. Given the high spatial and temporal variation in Bti-abundance, it cannot be ruled out that continued VectoBac-G® application in this area might result in more pronounced increases in abundance. In line with this, Guidi et al. [8] found a positive relationship between the number of treatments and Bti-abundances after 22 years of mosquito control. Some of our treated sites were not treated in 2012 (the year before sampling) but only in previous years, and no Bti was detected in those sites. In addition, the abundance of Bti in treated subsites in May exceeded the total number of spores added by VectoBac-G® application since 2001 . However, 5 months later in October, Bti was not detected in the same subsites. This indicates that the majority of added spores are inactivated, decomposed or dispersed within one year after application, in accordance with previous studies [8, 15, 32].

\section{Detection Sensitivity}

In most of our samples, Bti-abundance was below the detection level. According to the dilution standard curves for the qPCR, the detection threshold was between 6 and 60 gene targets per PCR. However, there were significant influences of soil characteristics on Bti quantification and recovery. When soil samples from sites with varying soil properties are included, as done in the present study, it is difficult to account for inhibition of PCR, since it depends on soil type. Still, the amount of soil DNA extracts used for PCR could possibly be further optimized and inhibition reduced as described previously [16, 33, 34].

The DNA extraction efficiency of the present study was comparable with the efficiencies obtained by Guidi et al. [20]. However, the variation among soil samples and replicates was high (Table 2). Guidi et al. [20] tested only one high spore concentration $\left(10^{6}\right.$ spores $^{-1}$ soil) whereas three different spore concentrations between $3.7 \times 10^{4}$ and $3.7 \times 10^{6}$ spores $^{-1}$ soil were tested in the present study. It is expected that extraction efficiencies will be lower when adding lower numbers of spores to the soil, particularly when approaching the quantification limit, and such a trend could also be seen in the present study.

\section{Conclusions}

Overall, long-term applications of VectoBac-G® had negligible effects on total Bcg-abundance and moderate effects on Bti-abundance. With a theoretical average increase of the abundance of Bcg of less than $30 \%$ by one VectoBac-G®application, it is not surprising that we registered no overall treatment effect on the Bcg population size. These results imply that it is unlikely that 10 years of Bti use in the River Dalälven floodplains has changed the Bti- and Bcgabundances to a degree that could have permanent effects on target or non-target dipteran larvae or other organisms. Thus, our study increases the understanding of potential long-term effects of biological control of mosquito larvae in the environment by applying Bti-based products.

Acknowledgments We thank the anonymous reviewer for the valuable comments on the manuscript. The project was funded by the Carl Trygger Foundation (contract CTS 11: 452) and the Centre for Biological Control (CBC; http://www.slu.se/cbc) at the Swedish University of Agricultural Sciences (SLU).

\section{References}

1. Vilas-Bôas GT, Peruca APS, Arantes OMN (2007) Biology and taxonomy of Bacillus cereus, Bacillus anthracis, and Bacillus thuringiensis Can. J. Microbiol. 53:673-687. doi:10.1139/W07-029

2. Hendriksen NB (2016) The two lives of Bacillus thuringiensis: response to Ruan et al. and Loguercio and Argôlo-Filho Trends Microbiol. 24:1-2. doi:10.1016/j.tim.2015.10.010

3. Ceuppens S, Boon N, Uyttendaele M (2013) Diversity of Bacillus cereus group strains is reflected in their broad range of pathogenicity and diverse ecological lifestyles FEMS Microbiol. Ecol. 84: 433-450. doi:10.1111/1574-6941.12110

4. Rasko D, Altherr M, Han C, Ravel J (2005) Genomics of the Bacillus cereus group of organisms FEMS Microbiol. Rev. 29: 303-329. doi:10.1016/j.femsre.2004.12.005

5. Lacey LA, Grzywacz D, Shapiro-Ilan DI, Frutos R, Brownbridge M, Goettel MS (2015) Insect pathogens as biological control agents: back to the future J. Invertebr. Pathol. 132:1-41. doi:10. 1016/j.jip.2015.07.009

6. Lacey LA (2007) Bacillus thuringiensis serovariety israelensis and Bacillus sphaericus for mosquito control J. Am. Mosq. Control Assoc. 23:133-163. doi:10.2987/8756-971X(2007)23[133: BTSIAB]2.0.CO;2

7. Bravo A, Likitvivatanavong S, Gill SS, Soberón M (2011) Bacillus thuringiensis: a story of a successful bioinsecticide Insect Biochem. Mol. Biol. 41:423-431. doi:10.1016/j.ibmb.2011.02.006

8. Guidi V, Patocchi N, Lüthy P, Tonolla M (2011) Distribution of Bacillus thuringiensis subsp. israelensis in soil of a Swiss wetland reserve after 22 years of mosquito control Appl. Environ. Microbiol. 77:3663-3668. doi:10.1128/aem.00132-11

9. Becker N (1997) Microbial control of mosquitoes: management of the Upper Rhine mosquito population as a model programme Parasitol. Today 13:485-487. doi:10.1016/S0169-4758(97)01154-X

10. Boyer S, Tilquin M, Ravanel P (2007) Differential sensitivity to Bacillus thuringiensis var. israelensis and temephos in field mosquito populations of Ochlerotatus cataphylla (Diptera: Culicidae): 
toward resistance? Environ. Toxicol. Chem. 26:157-162. doi:10. 1897/06-205R.1

11. Lévêque C, Hougard JM, Resh V, Statzner B, Yaméogo L (2003) Freshwater ecology and biodiversity in the tropics: what did we learn from 30 years of Onchocerciasis control and the associated biomonitoring of West African rivers? Hydrobiologia 500:23-49. doi:10.1023/A:1024660017077

12. Hongyu Z, Changju Y, Jingye H, Lin L (2004) Susceptibility of field populations of Anopheles sinensis (Diptera: Culicidae) to Bacillus thuringiensis subsp. israelensis Biocontrol Sci. Tech. 14: 321-325. doi:10.1080/09583150310001639187

13. Lundström JO, Schäfer ML, Petersson E, Persson Vinnersten TZ, Landin J, Brodin Y (2010) Production of wetland Chironomidae (Diptera) and the effects of using Bacillus thuringiensis israelensis for mosquito control Bull. Entomol. Res. 100:117-125. doi:10. 1017/S0007485309990137

14. Duchet C, Tetreau G, Marie A, Rey D, Besnard G, Perrin Y, Paris M, David J-P, Lagneau C, Després L (2014) Persistence and recycling of bioinsecticidal Bacillus thuringiensis subsp. israelensis spores in contrasting environments: evidence from field monitoring and laboratory experiments Microb. Ecol. 67:576-586. doi:10. 1007/s00248-013-0360-7

15. Tetreau G, Alessi M, Veyrenc S, Périgon S, David J-P, Reynaud S, Després L (2012) Fate of Bacillus thuringiensis subsp. israelensis in the field: evidence for spore recycling and differential persistence of toxins in leaf litter Appl. Environ. Microbiol. 78:8362-8367. doi: 10.1128/AEM.02088-12

16. Schneider S, Hendriksen NB, Melin P, Lundström JO, Sundh I (2015) Chromosome-directed PCR-based detection and quantification of Bacillus cereus group members with focus on B. thuringiensis serovar israelensis active against nematoceran larvae Appl. Environ. Microbiol. 81:4894-4903. doi:10.1128/AEM.00671-15

17. Schäfer ML, Lundström JO (2014) Efficiency of Bti-based floodwater mosquito control in Sweden-four examples J Eur Mosq Control Assoc 32:1-8

18. Travers RS, Martin PAW, Reichelderfer CF (1987) Selective process for efficient isolation of soil Bacillus spp Appl. Environ. Microbiol. 53:1263-1266

19. Donnarumma F, Paffetti D, Stotzky G, Giannini R, Vettori C (2010) Potential gene exchange between Bacillus thuringiensis subsp. kurstaki and Bacillus spp. in soil in situ Soil Biol. Biochem. 42: 1329-1337. doi:10.1016/j.soilbio.2010.03.014

20. Guidi V, De Respinis S, Benagli C, Lüthy P, Tonolla M (2010) A real-time PCR method to quantify spores carrying the Bacillus thuringiensis var. israelensis cry4Aa and cry4Ba genes in soil J. Appl. Microbiol. 109:1209-1217. doi:10.1111/j.1365-2672.2010. 04741.x

21. Fournier DA, Skaug HJ, Ancheta J, Ianelli J, Magnusson A, Maunder MN, Nielsen A, Sibert J (2012) AD model builder: using automatic differentiation for statistical inference of highly parameterized complex nonlinear models Optim Methods Softw 27:233249. doi:10.1080/10556788.2011.597854

22. Development Core Team R (2012) R: a language and environment for statistical computing. R Foundation for Statistical Computing, Vienna, http://www.R-project.org

23. Venables WN, Ripley BD (2002) Modern applied statistics with S. R package version 7.2-45. In: Venables WN, Ripley BD. http:/ www.stats.ox.ac.uk/pub/MASS4/

24. Fox J, Weisberg S (2011) An $\{\mathrm{R}\}$ Companion to applied regression, Second edition. http://socserv.socsci.mcmaster.ca/jfox/Books/ Companion.

25. Lander JP (2016) coefplot: plots coefficients from fitted models. R package version 1.2.4. https://CRAN.R-project.org/package= coefplot.

26. Eskils K, Lövgren A (1997) Release of Bacillus thuringiensis subsp. israelensis in Swedish soil FEMS Microbiol. Ecol. 23: 229-237. doi:10.1111/j.1574-6941.1997.tb00405.x

27. Hendriksen NB, Hansen BM (2002) Long-term survival and germination of Bacillus thuringiensis var. kurstaki in a field trial Can. J. Microbiol. 48:256-261. doi:10.1139/w02-009

28. Raymond B, Johnston PR, Nielsen-LeRoux C, Lereclus D, Crickmore N (2010) Bacillus thuringiensis: an impotent pathogen? Trends Microbiol. 18:189-194. doi:10.1016/j.tim.2010.02.006

29. Bizzarri MF, Bishop AH (2007) Recovery of Bacillus thuringiensis in vegetative form from the phylloplane of clover (Trifolium hybridum) during a growing season J. Invertebr. Pathol. 94:3847. doi:10.1016/j.jip.2006.08.007

30. Wakisaka Y, Masaki E, Nishimoto Y (1982) Formation of crystalline delta-endotoxin or poly-beta-hydroxybutyric acid granules by asporogenous mutants of Bacillus thuringiensis Appl Env Microbiol 43:1473-1480

31. Blume H-P, Brümmer GW, Fleige H, Horn R, Kandeler E, KögelKnabner I, Kretzschmar R, Stahr K, Wilke B-M (2016) Soil organisms and their habitat. In: Scheffer F, Schachtchabel P (eds) Soil Science. Springer, Berlin Heidelberg, pp. 87-122

32. De Respinis S, Demarta A, Patocchi N, Lüthy P, Peduzzi R, Tonolla M (2006) Molecular identification of Bacillus thuringiensis var. israelensis to trace its fate after application as a biological insecticide in wetland ecosystems Lett. Appl. Microbiol. 43:495-501. doi: 10.1111/j.1472-765X.2006.01999.x

33. Schneider S, Rehner SA, Widmer F, Enkerli J (2011) A PCR-based tool for cultivation-independent detection and quantification of Metarhizium clade 1 J. Invertebr. Pathol. 108:106-114. doi:10. 1016/j.jip.2011.07.005

34. Schneider S, Enkerli J, Widmer F (2009) A generally applicable assay for the quantification of inhibitory effects on PCR J. Microbiol. Methods 78:351-353. doi:10.1016/j.mimet.2009.06.010 